\title{
FLOOD DISASTER STUDIES: A REVIEW OF REMOTE SENSING PERSPECTIVE IN CAMBODIA
}

\author{
Chhuonvuoch KOEM ${ }^{1}$ (D), Sarintip TANTANEE ${ }^{1 * \text { (D) }}$
}

DOI: $10.21163 /$ GT_2021.161.02

\begin{abstract}
:
Flood is the most critical natural disaster in Asia. It is also the most affected disaster in Cambodia. The solution must be made to manage the disaster from being interrupting people. The purposes of the study are to identify the 2011 flood impact spatial distribution, evaluate how RS has been applied to flood analysis, and assess the gaps of RS for flood analysis over Cambodia. The flood impact can be calculated by using a weighted arithmetic mean (WAM). The flood studies can be accessed through several literary databases. The 2011 flood impacts commonly located in the regions of Tonle Sap and Mekong River. Furthermore, other regions were affected. Fourteen articles have been found, which are six flood hazard mappings, seven flood risk assessments, and one flood damage assessment. Most of the study covered the Mekong River and Tonle Sap Lake catchments; however, there are still lacking studies over other affected areas. Besides, flood forecasting and flood early warning were not paid attention. Due to the limitation of rain gauge stations, RS is very important to apply for flood studies. Likewise, the radar composite with the neighboring countries is useful since some parts of the borders were blocked by the mountains. In brief, this review could generate greater ideas and solutions for further flood studies efficiency.
\end{abstract}

Key-words: Flood, Remote Sensing, GIS, TRMM, Cambodia

\section{INTRODUCTION}

Flood is a common hazard of all-natural hazards in the world. River flood results from the water level overtop of the riverbank both natural and artificial that interrupt human life and properties. River flood typically unfolds several days or even months due to its occurrence in the large basin (Smith \& Petley, 2009). The flood occurs when the water level increases due to the failure of technical infrastructures or heavy rainfall over the capacity of the storage (Ranke, 2016). Flash flood occurs when the water rises during or within a few hours of rainfall (Doswell, 2003). Floods cause negative effects both direct and indirect to human lives, environment, ecosystem, transportation, infrastructure, agriculture, cultural heritage, economic, etc. (Yu et al., 2012). Conversely, the annual monsoon flood plays a significant role in providing nutrients and enriching soil (Manh et al., 2014).

Cambodia is located in one part of the Asia continent with the land of $181,035 \mathrm{~km}^{2}$. It consists of mountains, plains, and a great river and lake. The climate is monsoon, which consists of a couple of seasons including the rainy season (May-Oct) and the dry season (Nov-Apr). The rainy season is recognized by a strong wind, high humidity, and heavy rainfall (about $85 \%$ of annual rainfall). The dry season is categorized by wind and low humidity. According to Thoeun (2015), the average annual rainfall is $1,400 \mathrm{~mm}$ in the flat region and $4,000 \mathrm{~mm}$ in the coastal and high regions. The mean temperature, additionally, is $28^{\circ} \mathrm{C}$. The temperature in January is $17^{\circ} \mathrm{C}$ then it increases to $38^{\circ} \mathrm{C}$ in April. The total population is 16.2 million. The country is internationally known as one of the most susceptibility nations to climate change (Kreft et al., 2017). The country is listed in the rank of 19, high risk, to climate risk index and 54, medium risk, to risk index. The most common hazard in Cambodia is associated with floods (UNDRR, 2019). In 2017, the score of hazard and explorer risk, vulnerability, and lack of capacity are $4.8,3.0$, and 6.5 respectively. The economic loss due to climate change was US $\$ 1.5$ billion or $10 \%$ of GDP in 2015 . It was estimated to decrease by at least $2.5 \%$ by 2030 and $10 \%$ by 2050 (CFE-DM, 2017).

\footnotetext{
${ }^{I}$ Naresuan University, Faculty of Engineering, Center of Excellence on Energy Technology and Environment, Phitsanulok6500,Thailand,chhuonvuochk62@email.nu.ac.th,sarintipt@nu.ac.th
} 
Flood is a natural disaster that threatens sustainable development (CamDi, 2013), and it the most frequent hazard occurring in Cambodia (72\%). The floods cause the most death $(97.4 \%)$ and the largest economic destruction (91.1\%) among disasters. During the rainy season, the Mekong River and Tonle Sap create unique river floods and flash floods, especially during the post-season. The country is affected by the overspill of Tonle Sap and Mekong River, which courses flooding in several provinces. Cambodia faced serious floods in 2000, 2011, and 2013. The 2011 major flood caused 250 people died and 23 people sustained injuries. It affected 18 provinces. There were 350,000 families (over 1.5 million individuals) affected, and 52,000 families were evacuated. Approximately 431,000 ha of rice field transplanting were affected, and paddy fields 267,000ha were damaged. Moreover, the national road around $925 \mathrm{~km}$ and urban roads $360 \mathrm{~km}$ were damaged. The estimation of the total loss of the 2011 flood to the economy was US\$ 630 million (CFE-DM, 2017). Therefore, the flood is the main problem, and it is a significant issue for research in Cambodia. In the existing advancing of Remote Sensing (RS), the specific flood events are more easily determine. Much research on flood has been studied depend on RS. Several researchers put more attempts to support flood disaster management such as Manzul Kumar Hazarika and Bormudoi (2007), Arias et al. (2012), Chung et al. (2019), and Kim et al. (2020). The aims of this paper are to (1) identify the spatial distribution of the 2011 flood impact, (2) evaluate how RS has been applied to flood analysis, and (3) find the gaps of RS for flood analysis over Cambodia. The main contribution of this review is the identification of broad and distinct patterns in terms of data source, method, spatial coverage, and result. Precisely, this paper can serve as a good foundation to develop the method of flood analysis with the help of RS that will lead to greater improvements in the field.

\section{METHODOLOGY}

According to the study's objectives, the methodology is separated into three different parts including spatial distribution of the 2011 flood impact, literature review of flood analysis using RS, and gaps of RS for flood analysis over Cambodia. Fig. 1 shows the methodology flowchart of the study. The review put efforts to evaluate flood analysis and find gaps of each study under the Remote Sensing perspective in Cambodia, the study intended to illustrate the 2011 flood impacts, the biggest flood as an example since it had the large extent and impact. Then the gaps could be found more precisely.

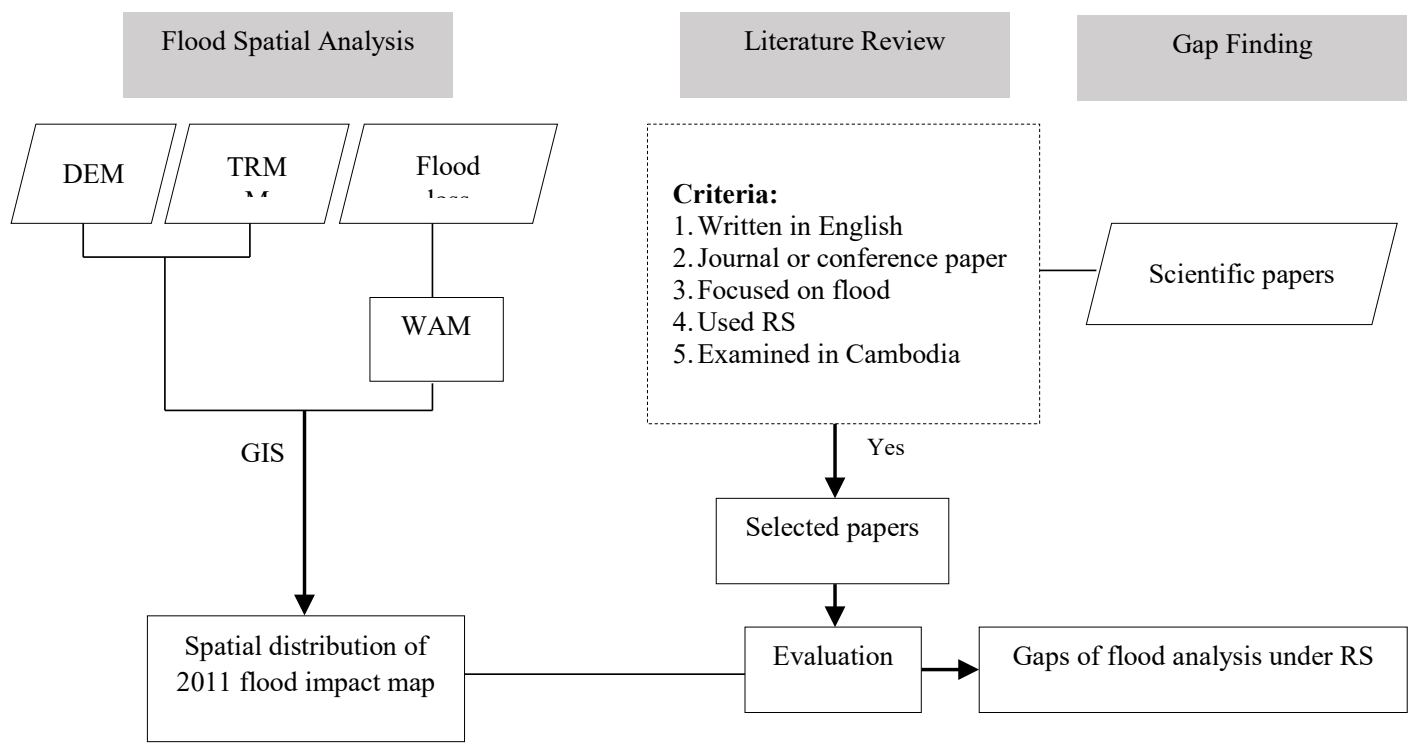

Fig. 1. Methodology flowchart. 
The spatial distribution of the flood impact was assessed with the help of GIS and Weight Arithmetic Mean (WAM) by using Eq. 1. The weights of different disaster impact are assigned based on the Jenks Natural Break Classification in GIS (Sharma et al., 2019). The weights are assigned 10 to death, 3 to injured, 3 to house destroyed, 1 to house damaged, 0.5 to cattle loss, and 0.5 to crop damaged. The higher value or score means a higher flood disaster loss.

$$
\mathrm{WAM}=\sum W_{i} X_{i} / \sum W_{i}
$$

where:

$\mathrm{W}_{\mathrm{i}}$ is the given weight of each parameter i, based on the study of Sharma et al. (2019).

$\mathrm{X}_{\mathrm{i}}$ is the type of flood impacts $\mathrm{i}$, which are the number of death, injured, house destroyed, house damaged, crop damaged, and cattle lost.

Flood impact data were obtained from the National Committee for Disaster Management in Cambodia (NCDM) and UNDP through the website http://www.ncdm.gov.kh/. Rainfall trends and distribution analysis are essential when deliberating flood analysis. Due to the spatial distribution of rain gauge stations in Cambodia is very few, and exited stations are not well maintained and monitored. Thus, it can limit the accessibility of rainfall data. The Tropical Rainfall Measuring Mission (TRMM) dataset obtained from NASA was used in this study. Matingo et al. (2018) assessed TRMM for flood assessment. To get the average rainfall data, 197 random points (a point/district) were used.

A literature review is used a systematical approach, which can reduce biases in selection and ensure all relevant articles. This approach is thorough, methodical, and orderly for considering articles for inclusion. The method consists of three steps. First, the papers were searched through five literary databases including Science Direct, Geographia Technica, Springer, MDPI, and Taylor \& Francis Online. Literature regarding flood disaster studies was searched starting by using "Flood analysis using Remote Sensing" as a keyword. The author searched the articles on 23 May 2020. Altogether, this keyword search yielded 1,657 results from Science Direct (2007-2021), 50 from Geographia Technica, 1,014 from Springer, 15 from MDPI-hydrology and environment, and 407 from Taylor \& Francis Online. Papers identified from the search are included in the review if they meet the selection criteria such as (1) written in English, (2) journal or conference paper, (3) focused on floods, (4) used remote sensing, and (5) examined in Cambodia. Then the authors reviewed the title and abstract to determine which articles meet the criteria. Second, the articles that met the criteria were reviewed in detail. In total, 14 articles met the criteria and were included in this review. The papers were noted the spatial coverage, data, method, and finding, which is easier to understand and evaluate. The gaps in each study were emphasized by look through some criteria. Is the study cover all the flood-affected areas in Cambodia? Do the studies cover all the flood assessment? Is there any platform of RS that did not use? These questions are considered to find the gaps in the flood analyses under the RS perspective in Cambodia.

\section{RESULT AND DISCUSSION}

\subsection{Spatial distribution of the 2011 flood impact}

Both overflow or river floods and flash floods caused severe damages in 2011. Floods occurred during the post-rainy season (Aug-Oct), and the early dry season (Nov). The flood had numerous impacts on people's lives, properties, agriculture, etc. Based on the calculation of WAM for the 2011 flood impact illustrates that 13 districts severely suffered (very high effect) from the flood among of all 197 districts in Cambodia (Table 1). Besides, there were 100 districts affected with high, moderate, and low effects. By using Jenks Natural Breaks Classification in GIS shows that the areas around Tonle Sap and Mekong River were numerously affected. Other regions in the northeast and upland areas are also affected during that time. Flood is dominant; therefore, it is worthy to discuss the rainfall pattern. Fig. 2 presents the spatial distribution of the 2011 flood impact and monthly average rainfall. 
Highest 2011 flood-affected districts.

Table 1.

\begin{tabular}{|c|c|c|c|c|c|c|c|}
\hline Province & District & $\begin{array}{c}\text { Death } \\
(\text { person/s) }\end{array}$ & $\begin{array}{l}\text { Injured } \\
\text { (person/s) }\end{array}$ & $\begin{array}{c}\text { House } \\
\text { destroyed } \\
\text { (house/s) }\end{array}$ & $\begin{array}{c}\text { House } \\
\text { damaged } \\
\text { (house/s) }\end{array}$ & $\begin{array}{c}\text { Crop } \\
\text { damaged } \\
\text { (ha) }\end{array}$ & WAM \\
\hline Siem Reap & Chi Kraeng & 2 & 4 & 2 & 4 & 17,727 & 495 \\
\hline Pursat & Bakan & 3 & 0 & 6 & 0 & 16,611 & 464 \\
\hline Kratie & Chhloung & 3 & 0 & 7 & 0 & 13,845 & 387 \\
\hline Kampong Thom & Stoung & 9 & 0 & 0 & 0 & 13,163 & 371 \\
\hline Pursat & Kandieng & 2 & 0 & 0 & 16 & 13,044 & 364 \\
\hline Prey Veng & Sithor Kandal & 3 & 0 & 0 & 48 & 12,503 & 351 \\
\hline Kampong Thom & Stung Sen & 7 & 0 & 0 & 0 & 12,350 & 347 \\
\hline Battambang & Sangkae & 4 & 0 & 2 & 0 & 11,830 & 331 \\
\hline Prey Veng & Pea Reang & 7 & 0 & 0 & 69 & 11,613 & 330 \\
\hline Kampong Cham & Batheay & 8 & 0 & 3 & 0 & 11,265 & 318 \\
\hline Svay Rieng & Kampong Rou & 1 & 0 & 5 & 0 & 10,938 & 305 \\
\hline
\end{tabular}

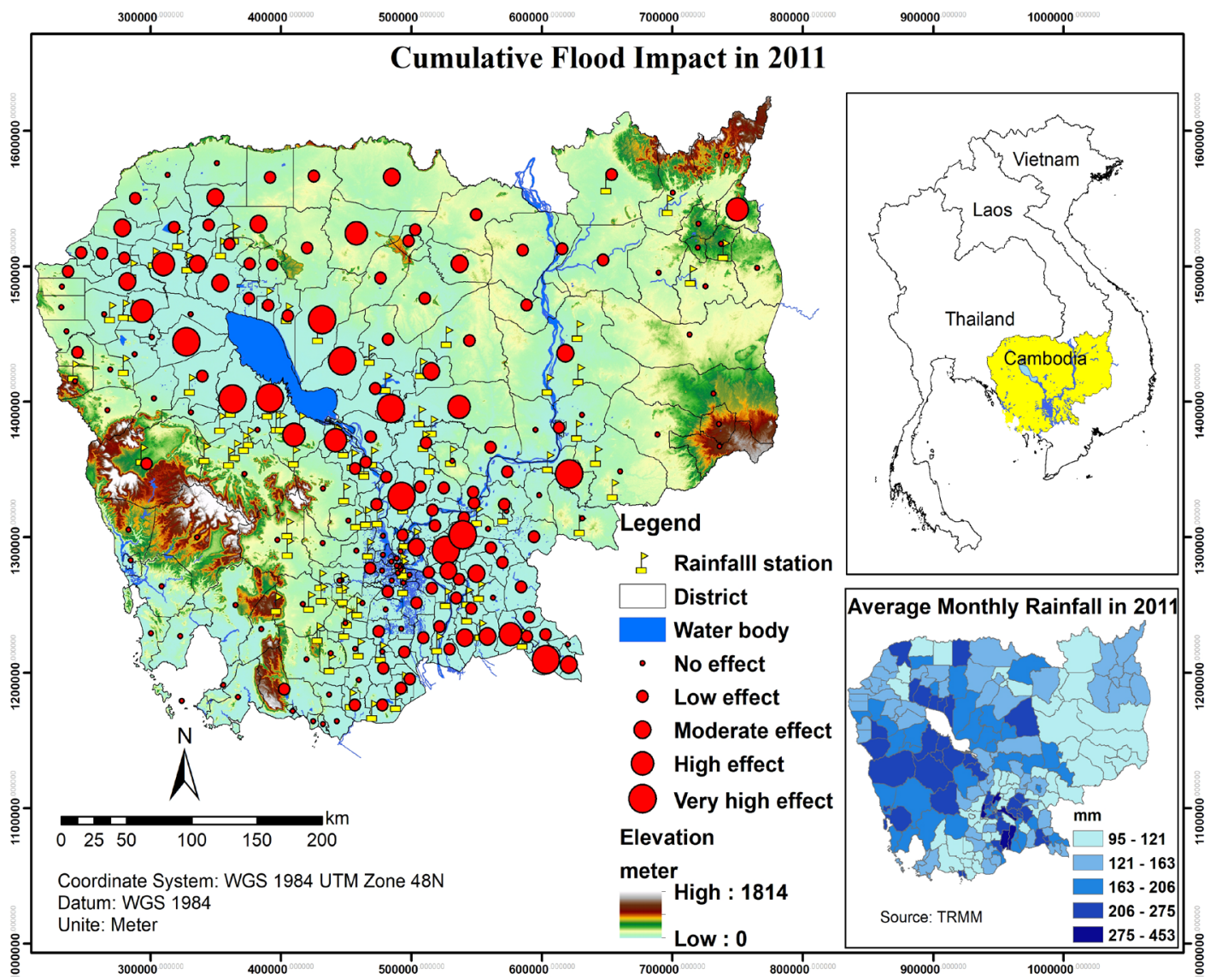

Fig. 2. Spatial distribution of flood impact and average monthly rainfall in 2011. 
Annual rainfall intensity and distribution are very vital when discussing the rainfall-induced flooding. Fig. 3 shows the rainfall with temporal distribution from 2000 to 2019 in Cambodia. TRMM data illustrated that $84 \%$ of the entire rainfall was distributed in the rainy season (May-Oct). More than $38 \%$ occurred in May, June, and July while $47 \%$ occurred in August, September, and October. However, there was only $16 \%$ occurring in the rest six months (Nov-Apr). It also shows that the distribution of rainfall in 2000 and 2011 are higher than other years.

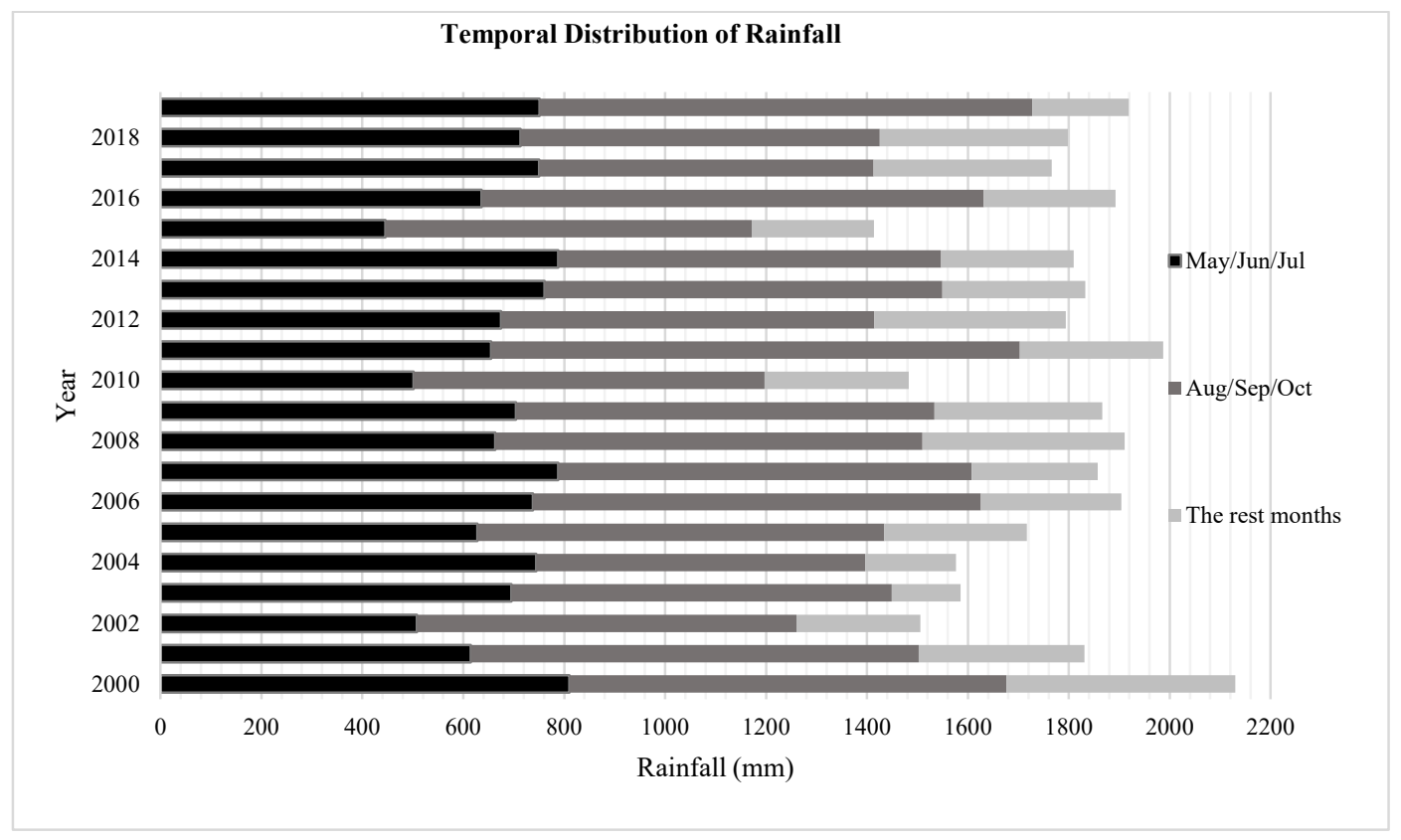

Fig. 3. Temporal distribution of rainfall in Cambodia from 2000-2019 (TRMM).

According to CamDi (2013), flood disasters including the Mekong flood, Tonle Sap flood, and flash floods usually happen during August, September, and October. During this period, the distribution of rainfall is very high if compared to other months. Rainfall 14\% occurred in August. About $18 \%$ of rainfall occurred in September whereas 13\% followed in October. September and October are categorized as the post-rainy season. More notably, August, September, and October are the flooding period and recognized as the peak-flooding period in Cambodia.

\subsection{RS application on flood analysis over Cambodia}

The development and strengthening of the legal framework for disaster management are prompted by the major occurrence disasters like the 2011 floods. There are several laws, policies, and strategic plans to shape DRR such as disaster management law, which was implemented in June 2015. Moreover, Cambodia joined AADMER, which is the ASEAN agreement on disaster management and emergency response together with Southeast Asian Nations. The national action plan for DRR (NAPDRR) is practiced along with the national strategic development plan (NSDP). These plans are updated every four years. To address the urgent, immediate needs, and adaptation to climate change, the national adaptation action platform was authorized in 2006. The NCDM is the leader of the DRR action plan, which focuses on the national level to the community level. Moreover, several types of researches including flood hazard mapping, flood risk assessment, and flood damage assessment have been conducted under the effort of DRR. These studies are very valuable for generating the idea and solutions for DRR. Although the limitation of the ground data created the difficulty of researching, RS provides global data cost-effectively. Under the perspective of RS, several types of flood analyses were carried out in various locations over Cambodia (Table 2). 
Table 2 .

List of flood studies in Cambodia.

\begin{tabular}{|c|c|c|c|c|c|}
\hline $\mathbf{N}$ & Areas & Data used & Method & Focus & Reference \\
\hline 1 & $\begin{array}{l}\text { Lower } \\
\text { Mekong } \\
\text { river }\end{array}$ & $\begin{array}{l}\text { Water level, discharge, RCS } \\
\text { GPS survey } \\
\text { RADARSAT-1 image } \\
\text { Landsat-ETM } \\
\text { Population, river, road }\end{array}$ & $\begin{array}{l}\text { HEC-RAS } \\
\text { AHP } \\
\text { Comparison }\end{array}$ & $\begin{array}{l}\text { Hazard flood } \\
\text { mapping }\end{array}$ & $\begin{array}{l}\text { Hazarika et } \\
\text { al. (2007) }\end{array}$ \\
\hline 2 & $\begin{array}{l}\text { Tonle Sap } \\
\text { Lake }\end{array}$ & $\begin{array}{l}\text { DEM } \\
\text { TRMM } \\
\text { Landsat and MODIS }\end{array}$ & $\begin{array}{l}\text { Regression } \\
\text { Monte Carlo } \\
\text { simulation }\end{array}$ & $\begin{array}{l}\text { The relationship } \\
\text { between flood, } \\
\text { precipitation, and } \\
\text { deforestation }\end{array}$ & $\begin{array}{l}\text { Kim et al. } \\
(2019)\end{array}$ \\
\hline 3 & $\begin{array}{l}\text { Angkor } \\
\text { Wat site }\end{array}$ & $\begin{array}{l}\text { PALSAR } \\
\text { DEM }\end{array}$ & AHP & $\begin{array}{l}\text { Flood hazard } \\
\text { zonation map }\end{array}$ & $\begin{array}{l}\text { Liu et al. } \\
\text { (2019) }\end{array}$ \\
\hline 4 & $\begin{array}{l}\text { Lower } \\
\text { Mekong } \\
\text { river }\end{array}$ & $\begin{array}{l}\text { DEM } \\
\text { Water level and discharge } \\
\text { UNOSAT }\end{array}$ & $\begin{array}{l}\text { HEC-RAS } \\
\text { Comparison }\end{array}$ & Flood map & $\begin{array}{l}\text { Ly et al. } \\
\text { (2018) }\end{array}$ \\
\hline 5 & $\begin{array}{l}\text { Mekong } \\
\text { River }\end{array}$ & $\begin{array}{l}\text { MODIS } \\
\text { Water level } \\
\text { Landsat }\end{array}$ & $\begin{array}{l}\text { EVI or NDVI } \\
\text { LSWI } \\
\text { WFFI }\end{array}$ & $\begin{array}{l}\text { Temporal change } \\
\text { in the extent of } \\
\text { annual flooding }\end{array}$ & $\begin{array}{l}\text { Sakamoto } \\
\text { et al. (2007) }\end{array}$ \\
\hline 6 & $\begin{array}{l}\text { Tonle Sap } \\
\text { River and } \\
\text { floodplain }\end{array}$ & $\begin{array}{l}\text { MODIS } \\
\text { DEM } \\
\text { Water level }\end{array}$ & $\begin{array}{l}\text { NDVI } \\
\text { MCL }\end{array}$ & $\begin{array}{l}\text { Seasonal changes } \\
\text { in inundation area } \\
\text { and water volume }\end{array}$ & $\begin{array}{l}\text { Siev et al. } \\
(2016)\end{array}$ \\
\hline 7 & $\begin{array}{l}\text { Whole } \\
\text { Cambodia }\end{array}$ & $\begin{array}{l}\text { MODIS } \\
\text { DEM } \\
\text { Radarsat-2 image } \\
\text { Population }\end{array}$ & $\begin{array}{l}\text { NDVI } \\
\text { Comparison } \\
\text { Probability of flood }\end{array}$ & $\begin{array}{l}\text { Multi-temporal } \\
\text { flood mapping }\end{array}$ & $\begin{array}{l}\text { Son et al. } \\
(2019)\end{array}$ \\
\hline 8 & $\begin{array}{l}\text { Stung Sen } \\
\text { River } \\
\text { basin }\end{array}$ & $\begin{array}{l}\text { DEM } \\
\text { Landsat image } \\
\text { Observe rainfall } \\
\text { Crop data } \\
\text { UNOSAT }\end{array}$ & $\begin{array}{l}\text { RRI } \\
\text { Relative damage } \\
\text { curves for paddy } \\
\text { rice crop } \\
\text { Comparison }\end{array}$ & Rice crop damage & $\begin{array}{l}\text { Chung et al. } \\
\text { (2019) }\end{array}$ \\
\hline 9 & $\begin{array}{l}\text { Tonle Sap } \\
\text { basin }\end{array}$ & $\begin{array}{l}\text { GRACE CSR-Release } 05 \\
\text { MODIS } \\
\text { TRMM }\end{array}$ & $\begin{array}{l}\text { GLDAS-NOAH } \\
\text { ERA } \\
\text { PCR-GLOBWB }\end{array}$ & $\begin{array}{l}\text { Water storage and } \\
\text { flood } \\
\text { identification }\end{array}$ & $\begin{array}{l}\text { Tangdamro } \\
\text { ngsub et al. } \\
\text { (2016) }\end{array}$ \\
\hline 10 & $\begin{array}{l}\text { Mekong } \\
\text { river }\end{array}$ & $\begin{array}{l}\text { DEM } \\
\text { Landsat-7 }\end{array}$ & $\begin{array}{l}\text { Linear binary } \\
\text { classifier } \\
\text { ROC }\end{array}$ & $\begin{array}{l}\text { Flood hazard } \\
\text { mapping }\end{array}$ & $\begin{array}{l}\text { Try et al. } \\
(2019)\end{array}$ \\
\hline 11 & $\begin{array}{l}\text { Southern } \\
\text { Cambodia } \\
\text {, along } \\
\text { Mekong }\end{array}$ & $\begin{array}{l}\text { MODIS } \\
\text { Landsat-7 ETM+ } \\
\text { Landsat-8 OLI } \\
\text { Daily water level }\end{array}$ & $\begin{array}{l}\text { WFFI } \\
\text { MNDWI }\end{array}$ & $\begin{array}{l}\text { Spatiotemporal } \\
\text { flood inundation } \\
\text { and land cover } \\
\text { change }\end{array}$ & $\begin{array}{l}\text { Vichet et al. } \\
\text { (2019) }\end{array}$ \\
\hline 12 & $\begin{array}{l}\text { Tonle Sap } \\
\text { lake }\end{array}$ & $\begin{array}{l}\text { MODIS } \\
\text { DEM } \\
\text { Observed rainfall }\end{array}$ & $\begin{array}{l}\text { RRI using } \\
\text { CAESAR- } \\
\text { LISFLOOD }\end{array}$ & $\begin{array}{l}\text { Hydrological } \\
\text { impacts on Tonle } \\
\text { Sap lake }\end{array}$ & $\begin{array}{l}\text { Yu et al. } \\
\text { (2019) }\end{array}$ \\
\hline 13 & $\begin{array}{l}\text { Lower } \\
\text { Mekong } \\
\text { river basin }\end{array}$ & $\begin{array}{l}\text { DEM } \\
\text { MODIS } \\
\text { GPM and TRMM } \\
\text { Temperature from GLDAS }\end{array}$ & $\begin{array}{l}\text { SWAT } \\
\text { Global reanalysis } \\
\text { weather data from } \\
\text { NCEP and CFSR }\end{array}$ & $\begin{array}{l}\text { Streamflow } \\
\text { variability }\end{array}$ & $\begin{array}{l}\text { Mohammed } \\
\text { et al. (2018) }\end{array}$ \\
\hline 14 & $\begin{array}{l}\text { Lower } \\
\text { Mekong } \\
\text { river }\end{array}$ & $\begin{array}{l}\text { Peak discharge } \\
\text { DEM }\end{array}$ & $\begin{array}{l}\text { Flood frequency } \\
\text { analysis } \\
\text { HEC-RAS }\end{array}$ & $\begin{array}{l}\text { Hazard flood map } \\
\text { and its return } \\
\text { period }\end{array}$ & $\begin{array}{l}\text { Kim et al. } \\
(2020)\end{array}$ \\
\hline
\end{tabular}

\subsubsection{Flood hazard mapping}

The flood disaster is the mixture of human susceptibility and physical exposure toward the geophysical process. The importance of flood damage is related to landuse, flood characteristics, and 
the capacity of people to cope with it (Smith \& Ward, 1998). Flood hazard mapping is significant for mitigation and prevention approaches (Radwan et al., 2018). It can be done by using flood modeling and RS data with the help of GIS. The hydraulic model is used to simulate the floods while the GIS environment can visualize the flood simulation result and hazard analysis. HEC-RAS is one of the popular opened source software with a Graphical User Interface (GUI) that can do hydraulic simulations and develop the flood maps for a river system of steady flow, unsteady flow, and sediment transport (Ly et al., 2018). Kim et al. (2020) used HEC-RAS combined with RS for flood hazard mapping in the Lower Mekong River. The study showed that 2011 and 2013 historical floods influenced most of the flood depth considering return periods. Additionally, Ly et al. (2018) applied HEC-RAS and RS to map hazard areas prone to flood in the Lower Mekong River. It illustrated that extent of the simulation flood was greater than the observed flood. It could be the result of model computation and insufficient data. The depth of the simulation flood was less than the observed overall. Regarding the comparison for verification of the simulated result, RS images can be used to compare the extent of floods. Moreover, microwave RS images can proceed as a base map for inundation areas since it can be obtained in all-weather conditions and all times. UNOSAT image was used to assess the capacity of HEC-RAS such as flood depth and flood extend. Most of the studies have used DEM of $30 \mathrm{~m}$ resolution; however, the errors have occurred as it cannot detail every elevation changing. Since the extraction and floodplain delineation is based on DEM, the higher resolution of DEM should be taken into account. Moreover, SWAT (Soil and Water Assessment) is a semi-distributed model interfaced with GIS that can identify surface runoff. SWAT can also use observed hydrological data to simulate the discharge, which is compatible with the actual data (Prasanchum et al., 2020) should be used. Still, HEC-RAS and RS combined with GIS provides an ability for flood mapping successfully. Hazarika et al. (2007) also used HEC-RAS and RS to map hazard areas prone to flood in four provinces in the Mekong River catchment. The RS data were used to validate simulated flood and generate the Manning's roughness coefficients. The studies found that most of the flood areas were agricultural areas with a maximum depth between $3.5 \mathrm{~m}$ to $6.5 \mathrm{~m}$. The combination of HEC-RAS and RS with the help of the GIS is effectively used for flood hazard mapping. Flood prevention and management are very crucial for sustainable development. The flood hazard mapping obtained by using SAR images from different years and flood hazard index (FHI) was developed to analyze the flood in the Angkor area. The area around Angkor Wat monuments must be monitored, and flood control measures should be taken into account to protect the site from flooding (Liu et al., 2019). MODIS and DEM were used to investigate the seasonal change of inundation areas and water volume and floodplain of Tonle Sap (Siev et al., 2016).

RS is cost-effective, and it is a suitable source to measure and monitor the floods while the number of hydrological stations is narrow. However, the resampling of the resolution of satellite data might have caused an error. Hence, the high resolution of the digital terrain model obtained from topographical maps should be taken into account. Try et al. (2019) used a Landsat-7 image to generate a flood map. Besides, satellite flood maps were needed to validate the result. The inundation modeling should be taken into account to enhance the predicted accuracy since the flood might be caused by other factors such as topographic condition, landuse change, climate change, etc. To analyze the spatiotemporal distribution of flood in the Southern, MODIS, Landsat-8 OLI, and Landsat-7 ETM+ were used. WWF algorithm for flood inundation detection was applied. The study concluded that the MODIS flood map can be applied to characterize the flooding (Vichet et al., 2019).

\subsubsection{Flood risk assessment}

The application of RS is very significant in disaster management, particularly in flood analysis from the perspective of Cambodia. It has obviously shown in Table 2 that most of the RS data have been used in flood risk assessment. Several researchers including Tangdamrongsub et al. (2016), Kim et al. (2019), and Yu et al. (2019) attempted to explore the different tools and techniques for flood risk in Tonle Sap. Tangdamrongsub et al. (2016) use the satellite observation including GRACE, MODIS, and TRMM to identify the flood and water storage by applying the PCR-CLOBWB hydrological model. The results demonstrate that it is a good agreement between the 8 -day averaged 
over monthly intervals of MODIS-derived TWS variations and the GRACE TWS variations. Therefore, GRACE data can be recognized as a sufficient tool for observing the small-scale hydrological basin. However, the high resolution of satellite images is still encouraged. Furthermore, Yu et al. (2019) has been used Rainfall Runoff Inundation (RRI) model to study hydrological impacts by using MODIS, DEM, and observed rainfall data. The use of the RRI model combined with DEM provides acceptable flooding areas by comparing with the MODIS observed flood map. It can solve the complex hydrological interaction between the Mekong River and Tonle Sap Lake. Regression analysis and Monte Carto simulation, which can predict future flood risk, were applied in Tonle Sap by using DEM, TRMM, Landsat, and MODIS. It concluded that both rainfall and deforestation deteriorated for flood risk. The flash flood frequency occurs in Tonle Sap during the heavy rainfall. Hence, the satellite information, especially TRMM, used in this study can provide a significant result to the analysis of flood severity, and it can be used to predict how the rainfall impacts the flood severity in the study area (Kim et al., 2019).

The recent hydrological circumstance and climate prediction can predict the temporal change of flooding. Sakamoto et al. (2007) studied the transformation of floods by using a wavelet-based filter (WFFI) and land surface water index (LSWI). They adopted MODIS, flood map, DEM, RADARSAT image, and observed water level. The simulated result has a margin of error related to resolution, but it correlates with the surface water obtained from the Landsat, RASARSAT, and hydrological data in terms of spatiotemporal changes. Flood assessment was prepared by Son et al. (2019) using MODIS, DEM, Radarsat-2, and population data. They applied the NDVI and comparison probability to map the multi-temporal flood. It showed that 32 districts were inundated. Besides, MODIS obtained in the rainy season was mostly covered by the cloud even they used the reconstruct cloud-affected value. It still has inappropriate artificial value for the analysis. Other factors also contributed to the error including mixed-pixel and low-resolution.

\subsubsection{Flood damage assessment}

The flood damage assessment is identical significant in providing potential risk information to support decision-makers and flood managers to reduce the diverse impacts. The general strategy to estimate the direct impact of the flood was using a relative flood damage curve. This curve discusses the relationship between flood characteristics such as depth, duration, and potential damage for objects. RS is one of the most effective tools to observe that provides flood and damage assessment information within cost-effectiveness. DEM, Landsat, Satellite flood map, boundary condition, observed rainfall, and paddy field data were used in flood damage assessment in Stung Sen catchment (Chung et al., 2019). RRI was applied to estimate the flood characteristics including flood level, length, and range. The satellite flood maps were compared with the simulated flood inundation areas. The result suggested that it is possible to use RRI and RS to identify the flood damage assessment. However, there were still some limitations concerning the absence of observed cross-section. The observed rainfall stations are limited, so rainfall-based satellites such as TRMM and GPM should be considered.

\subsection{Gaps of flood analysis under RS perspective}

Although several flood analyses have used RS combine with GIS effectively, the gaps still exist. Most of the flood analysis in Cambodia was focusing on overflow floods in the Tonle Sap catchment and along the Mekong River. However, the floods are not only occurring in those areas, but overflow floods and flash floods happen in other areas (Fig. 2). For example, the area located in the Northeast near the Lao border were classified as high flood impacts. Hence, these areas should have more researches on floods and flash floods. Furthermore, the flood analysis using RS over Cambodia frequently focused on flood risk assessment following by flood hazard mapping while flood damage assessment was only one study. Likewise, trustworthy and timely flood forecasting is a primary phase to disaster management whereas the early warning systems are very essential for mitigation measures. Flood forecasting and flood early warning, however, seem to be not interested in the researcher. Thus, further study should be focusing on flood forecasting and flood early warning. 
RS has been commonly used for mapping flood hazards, assessing flood risk, and assessing flood damage were DEM, MODIS, and Landsat. Most of the observed satellite flood map adopted in both flood risk assessment and flood hazard mapping is MODIS. PALSAR image, which is applicable while has a real-time flood monitoring; however, is rarely used because the frequent and open access to PALSAR is limited.

Moreover, several studies have claimed the error of flood extent due to the low resolution of DEM (30m). The low resolution of DEM cannot point each elevation changing; moreover, less crosssection creates inaccurate river bathymetric including extension and contraction. The high resolution of DEM, therefore, is needed to get more precise simulated results as the elevation extraction and floodplain delineation are established based on the DEM. Besides, the application of flood monitoring mainly depends on the availability and reliability of real-time precipitation. The data quality has to be strong.

Rain gauge stations over Cambodia are very few (98 stations) whereas its density is $54 \times 10^{-5}$ per $\mathrm{km}^{2}$ or $13.5 \times 10^{-4}$ per $25 \mathrm{~km}^{2}$. The rain gauges provide a spot sample of the rain dropping over a catchment; therefore, the number of gauges is essential to provide a consistent estimation of a catchment rainfall where rainfall slopes are marked. According to Ratnayaka et al. (2009), the minimum rain gauge density should be 1 per $25 \mathrm{~km}^{2}$ while the significant thunderstorm systems require 1 per $20 \mathrm{~km}^{2}$. Furthermore, Ground radar precipitation can be used for estimating a practical option for flood monitoring and forecasting. S-Band Doppler weather radar meteor 650C, which has a range of $450 \mathrm{~km}$ located in Phnom Penh was not used in any flood analysis over Cambodia.

Satellite data used in flood analysis over Cambodia.

Table 3.

\begin{tabular}{|c|c|c|c|}
\hline Focusing & Data & Method & Reference \\
\hline Flood hazard mapping & $\begin{array}{l}\text { Radarsat-1 } * \\
\text { Landsat-7 } * * \\
\text { PALSAR * } \\
\text { DEM } * * * * * \\
\text { UNOSAT } * \\
\text { MODIS } * \\
\text { Radarsat- } 2 *\end{array}$ & $\begin{array}{l}\text { HEC-RAS, } \\
\text { AHP, NDVI }\end{array}$ & $\begin{array}{l}\text { (Hazarika et al., 2007; Kim et al., } \\
\text { 2020; Liu et al., 2019; Ly et al., } \\
\text { 2018; Son et al., 2019; Try et al., } \\
\text { 2019) }\end{array}$ \\
\hline Flood risk assessment & $\begin{array}{l}\text { Envisat RA-2 * } \\
\text { DEM } * * * * \\
\text { TRMM } * * * \\
\text { Landsat } * * \\
\text { MODIS } * * * * * * * \\
\text { GRACE CSR-Release } 05 * \\
\text { Landsat-7/ETM }+* \\
\text { Landsat-8 OLI } * \\
\text { GPM * }\end{array}$ & $\begin{array}{l}\text { Monte Carlo, } \\
\text { EVI or NDVI, } \\
\text { RRI, SWAT }\end{array}$ & $\begin{array}{l}\text { (Kim et al., 2019; Mohammed et } \\
\text { al., 2018; Sakamoto et al., 2007; } \\
\text { Siev et al., 2016; } \\
\text { Tangdamrongsub et al., 2016; } \\
\text { Vichet et al., 2019; Yu et al., } \\
\text { 2019) }\end{array}$ \\
\hline $\begin{array}{l}\text { Flood damage } \\
\text { assessment }\end{array}$ & $\begin{array}{l}\text { DEM } * \\
\text { Landsat- } 8 * \\
\text { UNOSAT } *\end{array}$ & RRI & (Chung et al., 2019) \\
\hline
\end{tabular}

* is number of studies have been used

\subsection{Discussion}

The 2011 flood caused numerous losses to the country. Most of the affected areas were located in the Tonle Sap and Mekong River. Other areas located far from these two main water sources are also affected. According to CFE-DM (2017), Cambodia experiences flash floods once there is heavy rainfall through the rainy season, especially in August, September, and October. Moreover, it is affected by the slower but prolonged flooding from the overflow of Tonle Sap and Mekong River. However, several spatial coverages to floods were not paid attention; thus, there should be more studies concerning those areas. 
RS provides a powerful technique for object detection in inundation areas. The application of RS is weighty in DRR, particularly in flood disaster studies. Currently, RS has been extensively used in flood studies in Cambodia. Different satellite data have been used such as DEM, MODIS, TRMM, and Landsat images. However, the error related to image resolution is still the problem. The study of Arnesen et al. (2013) in the Amazon River adopted ALOS PALSAR with 12.5m resolution for flood observation. One national radar station can observe covering the whole country with the range of $450 \mathrm{~km}$, but some parts may be blocked by the high mountains especially in the Southwest, border to Thailand. The radar composite approach can be applied since several radars in Thailand cover some parts of Cambodia. However, the radar data in the country have not been used in any studies due to the limitation of data access.

Moreover, the distribution of rain gauge stations over the country is very few, and some of them are not well maintained (Fig. 2); therefore, data from satellites including TRMM, GPM, and TMPA are essential in flood studies. TRMM was used to validate the ground-based rainfall and replace the areas without or less observed rainfall stations. Iqbal and Athar (2018) used TMPA and TRMM to verify the observed rainfall over Pakistan by using different methods including RMSE, ME, MAE, and correlation coefficients. The result shows a strong correlation between the observed rainfall and satellite rainfall. TRMM and TMPA are very suitable for the areas without or not enough observed rainfall stations. Thus, satellite-based rainfall can be used to replace the areas without rain gauge stations.

Since the map is the most common geographical representation of reality, the flood map is presently being used in various disaster management practices. The accuracy and verification can be found by using the hydraulic model (Horritt, 2006) or satellite flood maps from different sources such as MODIS (Sakamoto et al., 2007) and satellite flood images from UNOSAT along with the verification equations (Ly et al., 2018). The random forest (RF) model was used in the flood vulnerability mapping in mountainous areas in China. It can hold great datasets through factor contribution examination. It also Supports Vector Machine methods (SVM) (Zhao et al., 2018). Furthermore, the AHP model combined with GIS and RS was used for mapping the area prone to flash flood. This method can be applied in the concept of Cambodia since data are finable (Mohamed, 2019). Besides, the SWAT and GUMBEL distribution method used for simulating flood risk areas and creating the river route based on DEM was carried out in Yang catchment, Thailand (Prasanchum et al., 2020). SWAT model can simulate the watershed delineation to distinct the entire areas into subcatchments, which allows users to distinguish the discharge of each catchment.

\section{CONCLUSION}

The purposes of this paper are to identify the spatial distribution of the 2011 flood impact, evaluate how RS has been applied in flood studies, and find the gaps of each study under RS perspective over Cambodia. It is found that several gaps are identified such as the lack of studies on the other flood-affected areas, the error due to the satellite image resolution, the focused parts of flood analysis, and the limitation of rain gauges stations. The 2011 floods caused numerous impacts. Many studies have been focusing on Tonle Sap and Mekong River regions; however, floods do not only occur in those areas. There should be more research in other flood-prone areas.

The models such as HEC-RAS and RRI with RS data have been used in most studies due to its efficiency in simulating and providing satisfying results. However, it is suggested that sufficient data and field surveying such as cross-section and floodplain should be taken into account to run this model in future studies. Moreover, the low resolution of DEM caused the error to the results since it cannot detail all elevation changes. The high-resolution DEM, therefore, is needed for a better result. Additionally, flood forecasting and flood early warning, which are very essential for disaster management, was not carried out in the studies. Furthermore, the satellite-based rainfall like TRMM is very important since the distribution of rain gauge stations over Cambodia is limited. Moreover, the radar composite should be considered since it can provide more accuracy of data. 


\section{REFERENCES}

Arias, M. E., Cochrane, T. A., Piman, T., Kummu, M., Caruso, B. S., \& Killeen, T. J. (2012). Quantifying changes in flooding and habitats in the Tonle Sap Lake (Cambodia) caused by water infrastructure development and climate change in the Mekong Basin. $J$ Environ Manage, 112, 53-66. https://doi.org/10.1016/j.jenvman.2012.07.003

Arnesen, A. S., Silva, T. S. F., Hess, L. L., Novo, E. M. L. M., Rudorff, C. M., Chapman, B. D., \& McDonald, K. C. (2013). Monitoring flood extent in the lower Amazon River floodplain using ALOS/PALSAR ScanSAR images. Remote Sensing of Environment, 130, 51-61. https://doi.org/10.1016/j.rse.2012.10.035

CamDi. (2013). Cambodia disaster loss and damage analysis report 1999-2013. Phnom Penh: National Committee for Disaster Management and United Nation Development Programme.

CFE-DM. (2017). Cambodia Disaster Management Handbook. Phnom Penh: Center for Excellence in Disaster Management \& Humanitarian Assistance.

Chung, S., Takeuchi, J., Fujihara, M., \& Oeurng, C. (2019). Flood damage assessment on rice crop in the Stung Sen River Basin of Cambodia. Paddy and Water Environment, 17(2), 255-263. https://doi.org/10.1007/s10333-019-00718-1

Doswell, C. A. (2003). Flooding. the United States of America: Elsevier Science

Hazarika, M. K., \& Bormudoi, A. (2007). Flood Hazard Mapping in Four Provinces of Cambodia Under the Mekong River Basin. 5th AMFF - Improving Inputs towards Medium Term Flood Forecasting and Warning in the Mekong Basin. https://www.researchgate.net/publication/262270027

Hazarika, M. K., Bormudoi, A., Kafle, T. P., Samarkoon, L., Nuon, K., Savuth, Y., \& Narith, R. (2007). Flood Hazard Mapping in Four Provinces of Cambodia Under the Mekong River Basin. Paper presented at the 5th AMFF - Improving Inputs towards Medium Term Flood Forecasting and Warning in the Mekong Basin.

Horritt, M. S. (2006). A methodology for the validation of uncertain flood inundation models. Journal of Hydrology, 326(1-4), 153-165. https://doi.org/10.1016/j.jhydrol.2005.10.027

Iqbal, M. F., \& Athar, H. (2018). Validation of satellite based precipitation over diverse topography of Pakistan. Atmospheric Research, 201, 247-260. https://doi.org/10.1016/j.atmosres.2017.10.026

Kim, S., Sohn, H.-G., Kim, M.-K., \& Lee, H. (2019). Analysis of the Relationship among Flood Severity, Precipitation, and Deforestation in the Tonle Sap Lake Area, Cambodia Using Multi-Sensor Approach. KSCE Journal of Civil Engineering, 23(3), 1330-1340. https://doi.org/10.1007/s12205-019-1061-7

Kim, V., Tantanee, S., \& Suparta, W. (2020). Gis-Based Flood Hazard Mapping Using Hec-Ras Model: A Case Study of Lower Mekong River, Cambodia. Geographia Technica, 15(1), 16-26. https://doi.org/10.21163/gt 2020.151.02

Kreft, S., Eckstein, D., \& Melchior, I. (2017). Who suffers most from extreme weather events? Weather-related loss events in 2015 and 1996 to 2015. Berlin: Germanwatch.

Liu, J., Xu, Z., Chen, F., Chen, F., \& Zhang, L. (2019). Flood Hazard Mapping and Assessment on the Angkor World Heritage Site, Cambodia. Remote Sensing, 11(1), 98. https://doi.org/10.3390/rs11010098

Ly, S., Kim, L., Demerre, S., \& Heng, S. (2018). Flood Mapping along the Lower Mekong River in Cambodia. Engineering Journal, 22(1), 269-278. https://doi.org/10.4186/ej.2018.22.1.269

Manh, N. V., Dung, N. V., Hung, N. N., Merz, B., \& Apel, H. (2014). Large-scale suspended sediment transport and sediment deposition in the Mekong Delta. Hydrology and Earth System Sciences, 18(8), 3033-3053. https://doi.org/10.5194/hess-18-3033-2014

Matingo, T., Gumindoga, W., \& Makurira, H. (2018). Evaluation of sub daily satellite rainfall estimates through flash flood modeling in the Lower Middle Zambezi Basin. Proceedings of the International Association of Hydrological Sciences, 378, 59-65. https://doi.org/10.5194/piahs-378-59-2018

Mohamed, S. A. (2019). Application of satellite image processing and GIS-Spatial modeling for mapping urban areas prone to flash floods in Qena governorate, Egypt. Journal of African Earth Sciences, 158, 103507. https://doi.org/10.1016/i.jafrearsci.2019.05.015

Mohammed, I. N., Bolten, J. D., Srinivasan, R., \& Lakshmi, V. (2018). Satellite observations and modeling to understand the Lower Mekong River basin streamflow variability. J Hydrol (Amst), 564, 559-573. https://doi.org/10.1016/j.jhydrol.2018.07.030 
Prasanchum, H., Sirisook, P., \& Lohpaisankrit, W. (2020). Flood Risk Areas Simulation Using Swat and Gumbel Distribution Method in Yang Catchment, Northeast Thailand. Geographia Technica, 29-39. https://doi.org/10.21163/gt_2020.152.04

Radwan, F., Alazba, A. A., \& Mossad, A. (2018). Flood risk assessment and mapping using AHP in arid and semiarid regions. Acta Geophysica, 67(1), 215-229. https://doi.org/10.1007/s11600-018-0233-Z

Ranke, U. (2016). Natural Disaster Risk Management: Geosciences and Social Responsibility. New York: Springer.

Ratnayaka, D. D., Brandt, M. J., \& Johnson, K. M. (2009). Hydrology and Surface Supplies Water Supply (pp. 63-107): ScienceDirect.

Sakamoto, T., Van Nguyen, N., Kotera, A., Ohno, H., Ishitsuka, N., \& Yokozawa, M. (2007). Detecting temporal changes in the extent of annual flooding within Cambodia and the Vietnamese Mekong Delta from MODIS time-series imagery. Remote Sensing of Environment, 109(3), 295-313. https://doi.org/10.1016/j.rse.2007.01.011

Sharma, T. P. P., Zhang, J., Koju, U. A., Zhang, S., Baia, Y., \& Suwal, M. K. (2019). Review of flood disaster studies in Nepal: A remote sensing perspective. International Journal of Disaster Risk Reduction, 34, 1827. https://doi.org/10.1016/j.ijdrr.2018.11.022

Siev, S., Paringit, E., Yoshimura, C., \& Hul, S. (2016). Seasonal Changes in the Inundation Area and Water Volume of the Tonle Sap River and Its Floodplain. Hydrology, 3(4), 33. https://doi.org/10.3390/hydrology3040033

Smith, K., \& Petley, D. N. (2009). Environmental Hazards: Assessing Risk and Reducing Disaster (fifth ed.). Great Britain: Routledge.

Smith, K., \& Ward, R. (1998). Floods: Physical Processes and Human Impacts: Wiley.

Son, N.-T., Chen, C.-F., \& Chen, C.-R. (2019). Flood assessment using multi-temporal remotely sensed data in Cambodia. Geocarto International, 1-16. https://doi.org/10.1080/10106049.2019.1633420

Tangdamrongsub, N., Ditmar, P. G., Steele-Dunne, S. C., Gunter, B. C., \& Sutanudjaja, E. H. (2016). Assessing total water storage and identifying flood events over Tonlé Sap basin in Cambodia using GRACE and MODIS satellite observations combined with hydrological models. Remote Sensing of Environment, 181, 162-173. https://doi.org/10.1016/j.rse.2016.03.030

Thoeun, H. C. (2015). Observed and projected changes in temperature and rainfall in Cambodia. Weather and Climate Extremes, 7, 61-71. https://doi.org/10.1016/j.wace.2015.02.001

Try, S., Lee, G., Yu, W., \& Oeurng, C. (2019). Delineation of flood-prone areas using geomorphological approach in the Mekong River Basin. Quaternary International, 503, 79-86. https://doi.org/10.1016/j.quaint.2018.06.026

UNDRR. (2019). Disaster Risk Reduction in Cambodia: Status Report 2019. Retrieved from Bangkok, Thailand:

Vichet, N., Kawamura, K., Trong, D. P., On, N. V., Gong, Z., Lim, J., . . . Bunly, C. (2019). MODIS-Based Investigation of Flood Areas in Southern Cambodia from 2002-2013. Environments, 6(5), 57. https://doi.org/10.3390/environments6050057

Yu, Qin, X. S., \& Larsen, O. (2012). Joint Monte Carlo and possibilistic simulation for flood damage assessment. Stochastic Environmental Research and Risk Assessment, 27(3), 725-735. https://doi.org/10.1007/s00477$\underline{012-0635-4}$

Yu, W., Kim, Y., Lee, D., \& Lee, G. (2019). Hydrological assessment of basin development scenarios: Impacts on the Tonle Sap Lake in Cambodia. Quaternary International, 503, 115-127. https://doi.org/10.1016/i.quaint.2018.09.023

Zhao, G., Pang, B., Xu, Z., Yue, J., \& Tu, T. (2018). Mapping flood susceptibility in mountainous areas on a national scale in China. Sci Total Environ, 615, 1133-1142. https://doi.org/10.1016/j.scitotenv.2017.10.037 